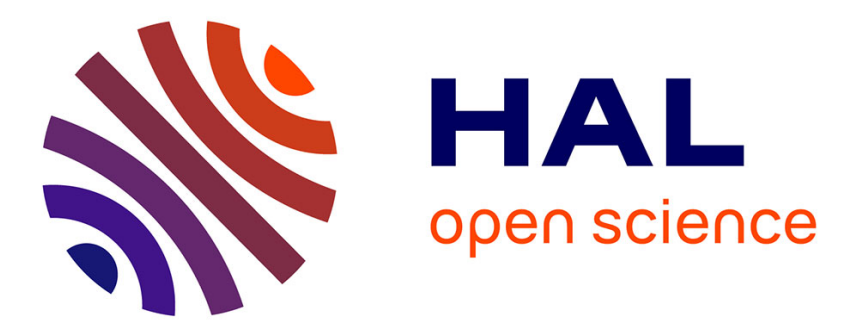

\title{
Spermiogenesis in the rainbow trout (Salmo gairdneri)
}

Roland Billard

\section{To cite this version:}

Roland Billard. Spermiogenesis in the rainbow trout (Salmo gairdneri). Cell and Tissue Research, 1983, 233, pp.265-284. 10.1007/BF00238295 . hal-02728452

\section{HAL Id: hal-02728452 \\ https://hal.inrae.fr/hal-02728452}

Submitted on 2 Jun 2020

HAL is a multi-disciplinary open access archive for the deposit and dissemination of scientific research documents, whether they are published or not. The documents may come from teaching and research institutions in France or abroad, or from public or private research centers.
L'archive ouverte pluridisciplinaire HAL, est destinée au dépôt et à la diffusion de documents scientifiques de niveau recherche, publiés ou non, émanant des établissements d'enseignement et de recherche français ou étrangers, des laboratoires publics ou privés.

\section{다(1) (2)}

Distributed under a Creative Commons Attribution - ShareAlikel 4.0 International 


\title{
Spermiogenesis in the rainbow trout (Salmo gairdneri)
}

\author{
An ultrastructural study \\ Roland Billard \\ I.N.R.A., Laboratoire de Physiologie des Poissons, Rennes, France
}

Summary. In an ultrastructural study on the spermiogenesis of the rainbow trout (Salmo gairdneri R.) four spermatogenetic stages were identified. In young round spermatids, the nuclear chromatin was first heterogeneous (euchromatin and heterochromatin). Subsequently, it became more homogeneous and started to condense in the form of coarse granules and fibers and then into fibrils associated in ribbon-like elements which eventually partly fused together. During early spermiogenesis, a juxtanuclear vacuole appeared in the area where the nuclear envelope was specialized due to condensation of material between the two envelopes and a slight accumulation of nuclear material. This area was finally located in the anterior part of spermatids and spermatozoa; it probably plays a role during fertilization. A flagellar rootlet appeared early in spermiogenesis; it may play a role in the attachment of the flagellum to the nucleus since it persisted until the centriolar complex was definitively fixed in the implantation fossa. The flagellum did not display a plasma membrane and was first located in the cytoplasm, but when it was later extruded from the cell, it acquired a membrane. The cytoplasm was rich in ribosomes (free or in small groups) but poor in membranous organelles. The few mitochondria polarized around the centriolar complex were finally organized into an annular mid-piece. The spermatids remained connected by intercellular bridges until the end of spermiogenesis. The complexity of trout spermiogenesis is intermediate between that in poecilids and that in carp and pike, which have very simple spermatozoa. The role of the material from the nucleus and the cytoplasm reaching the Sertoli cell in the control of spermatogenesis has been discussed.

Key words: Spermiogenesis - Rainbow trout - Ultrastructure - Spermatids - Chromatin

Send offprint requests to: Dr. Roland Billard, I.N.R.A. Laboratoire de Physiologie des Poissons, Campus de Beaulieu, F-35042 Rennes, France 
The formation of spermatozoa during the last phase of spermatogenesis, and especially the transformation of nuclear protein (Alfert 1956; Felix 1960; Dixon and Smith 1968; Davies et al. 1976), have been thoroughly studied by biochemical means. Some of the rare, detailed morphological studies that exist, however, indicate that spermiogenesis in salmonids has several particular characteristics.

An ultrastructural and morphometric stucy by Zirkin (1975) has shown that the process of chromatin condensation is complex. Important transformations, such as the temporary presence of flagellar rootlets, also affect the cytoplasmic organelles during the morphogenesis of spermatozoa (Billard 1972). No comprehensive study has been carried out on the entire process of spermiogenesis in one species. The present investigation is an approach to such a study in the rainbow trout (Salmo gairdneri).

\section{Materials and methods}

Adult male rainbow trout were obtained from various trout farms in the Paris area or from the trout breeding facility at our laboratory in Jouy-en-Josas; these fish had already had at least one reproductive cycle.

They were decapitated between September and February after anesthesia in a 2\% solution of MS222. Pieces from the middle of the testis were sampled and fixed for $1 \mathrm{~h}$ in a $3.3 \%$ glutaraldehyde solution in $0.1 \mathrm{M}$ phosphate buffer at $\mathrm{pH} 7.25$ and then fixed for $1 \mathrm{~h}$ in a $2 \%$ solution of osmium tetroxide in the same buffer; in some cases, the pieces were fixed directly in the osmium solution. After embedding in Epon, the pieces were cut into sections and stained with uranyl acetate and lead citrate for $5 \mathrm{~min}$ before they were covered with a carbon film for observation with a Siemens EM I electron microscope.

\section{Results}

Spermiogenesis in trout is divided into four stages which are described below and summarized in Table 1:

Stage 1. Immediately after the last maturation division of secondary spermatocytes, the round spermatids grouped in cysts are interconnected by intercellular bridges. In the nucleus, which remains spherical, granular filamentous chromatin is irregularly distributed (Figs. 1-3), with scattered perichromatin granules (Figs. 1-4) and dense bodies (Fig. 3) which might represent nucleolar remnants. The flagellum is formed in the cytoplasm early in this stage and remains inside the cytoplasm. The centriolar complex is surrounded by small vesicules (Fig. 1) and becomes connected to the nucleus by a flagellar rootlet (Fig. 2, Table 1). The membranous structures (Golgi apparatus and endoplasmic reticulum) of the cytoplasm are poorly developed; ribosomes are usually found free in the cytoplasm. Mitochondria with a dense matrix are polarized around the centriolar complex early in spermiogenesis (Fig. 2).

Another peculiarity of early spermiogenesis is the presence of a small vacuole in the anterior part of the nucleus in close contact with the nuclear envelope which is more dense (Fig. 3). This vacuole expands slightly (Fig. 4) 

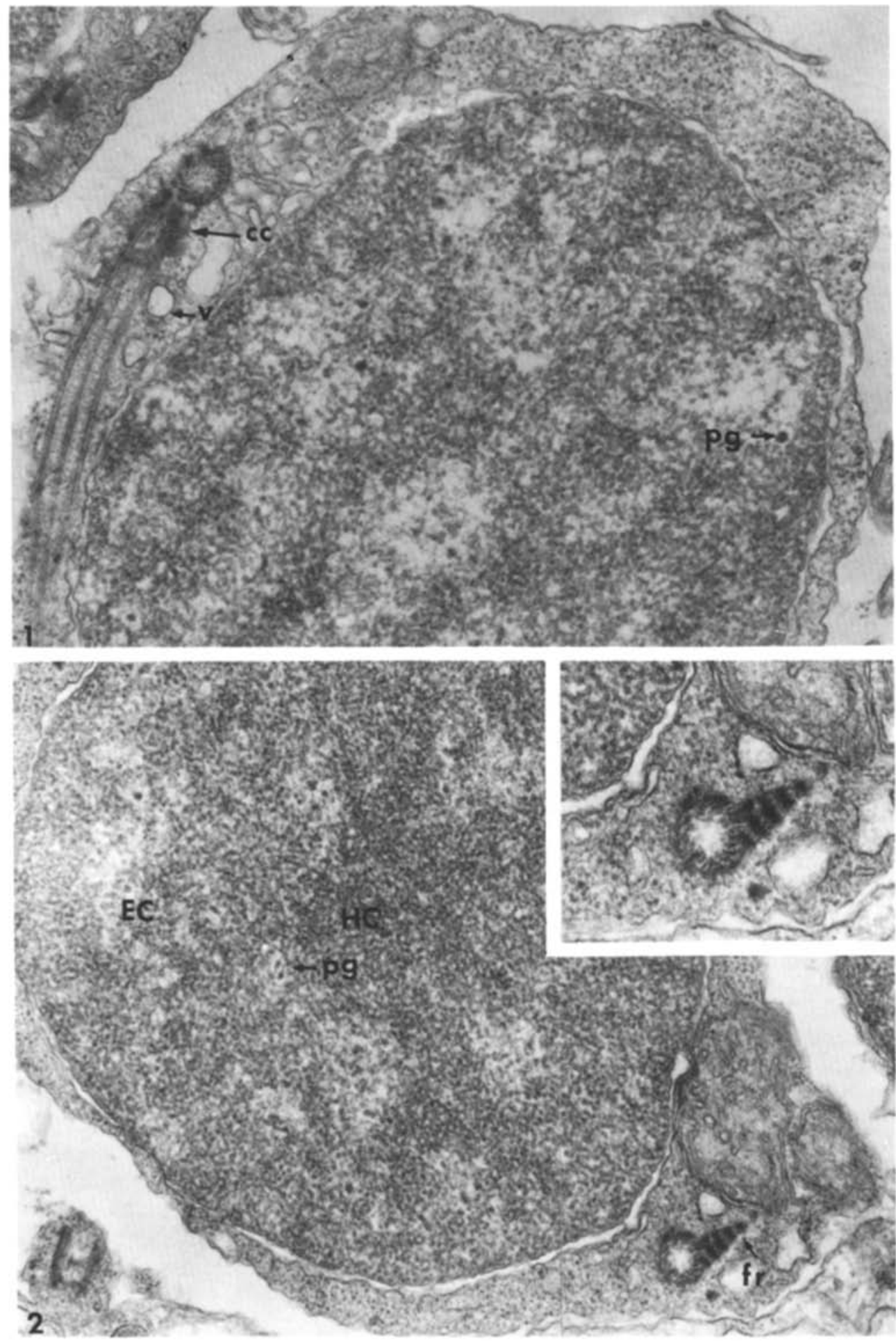

Fig. 1. Young round spermatid (stage 1). The flagellum is still in the cytoplasm. Numerous vesicles $(v)$ are seen around the centriolar complex $(c c) ; p g$ perichromatin granule. $\times 30000$

Fig. 2. Young round spermatid at stage I with a flagellar rootlet $(f r)$. The mitochondria start to concentrate around the centriolar complex. Nuclear material is heterogeneous with areas of heterochromatin $(H C)$ and euchromatin $(E C) . \times 25000$ 
Table 1. Summary of the major changes occurring during spermiogenesis in trout

\begin{tabular}{|c|c|c|c|c|}
\hline & Stage 1 & Stage 2 & Stage 3 & Stage 4 \\
\hline Shape of nucleus & round & round & $\begin{array}{l}\text { slightly } \\
\text { elongated }\end{array}$ & elongated \\
\hline Chromatin structure & $\begin{array}{l}\text { hetero- } \\
\text { geneous }\end{array}$ & homogeneous & $\begin{array}{l}\text { coarse } \\
\text { granules } \\
\text { and fibers }\end{array}$ & $\begin{array}{l}\text { fibrills } \\
\text { and fibers }\end{array}$ \\
\hline $\begin{array}{l}\text { Fiber diameter }(\mathrm{nm}) \text {, } \\
\text { thin (after Zirkin, } \\
\text { 1975), thick }\end{array}$ & $\begin{array}{l}17.7 \pm 3.4 \\
-\end{array}$ & $17.5 \pm 4$ & $\begin{array}{l}17.8 \pm 3.7 \\
326 \pm 71\end{array}$ & $-\overline{339} \pm 74$ \\
\hline Perichromatin granules & ++ & + & & \\
\hline Dense bodies & + & - & - & - \\
\hline Juxtanuclear vacuole & + & - & - & - \\
\hline $\begin{array}{l}\text { Differentiation } \\
\text { of nuclear envelope }\end{array}$ & + & + & + & $(+)$ \\
\hline $\begin{array}{l}\text { Centriolar complex: } \\
\text { position }\end{array}$ & cytoplasm & $\rightarrow$ nucleus & $\begin{array}{l}\text { implantation } \\
\text { fossa }\end{array}$ & $\begin{array}{l}\text { implantation } \\
\text { fossa }\end{array}$ \\
\hline attachment to nucleus & - & - & + & + \\
\hline rootlet & + & + & + & $+\rightarrow-$ \\
\hline Position of mitochondria & $\begin{array}{l}\text { peri- } \\
\text { centriolar }\end{array}$ & $\begin{array}{l}\text { peri- } \\
\text { centriolar }\end{array}$ & $\begin{array}{l}\text { peri- } \\
\text { flagellar }\end{array}$ & $\begin{array}{l}\text { ring, peri- } \\
\text { flagellar }\end{array}$ \\
\hline Intercellular bridges & + & + & + & + \\
\hline Cytoplasm & $\begin{array}{l}\text { around } \\
\text { spermatid }\end{array}$ & $\begin{array}{l}\text { leave } \\
\text { anterior } \\
\text { part }\end{array}$ & $\begin{array}{l}\text { pushed } \\
\text { backward }\end{array}$ & $\begin{array}{l}\text { latero- } \\
\text { posterior }\end{array}$ \\
\hline Flagellum & $\begin{array}{l}\text { intra- } \\
\text { cytoplasmic }\end{array}$ & $\begin{array}{l}\text { extra- } \\
\text { cellular }\end{array}$ & $\begin{array}{l}\text { extra- } \\
\text { cellular }\end{array}$ & $\begin{array}{l}\text { extra- } \\
\text { cellular }\end{array}$ \\
\hline
\end{tabular}

and eventually disappears, but the modified nuclear envelope with dense material between the two layers remains.

Stage 2. During this stage the nucleus is spherical and the chromatin is homogeneously distributed. Some perichromatin granules remain (Fig. 5) but there is no trace of the dense body. In the cytoplasm, free ribosomes are still numerous and the mitochondria remain located towards the anterior part of the flagellum where the first signs of organization of the middle piece appear (Fig. 5). The centriolar complex is still connected to the nuclear envelope by a flagellar rootlet (Fig. 5). The flagellum, which appeared earlier in the cytoplasm (Fig. 1), was apparently translocated under the plasma membrane and then seemed to emerge from the cell from this point. The plasma membrane of the flagellum with its lateral expansions also appeared to be formed at that time.

Stage 3. During stage 3 , the nucleus elongates slightly and its rotation becomes symmetric due to the implantation of the centriolar complex in the 

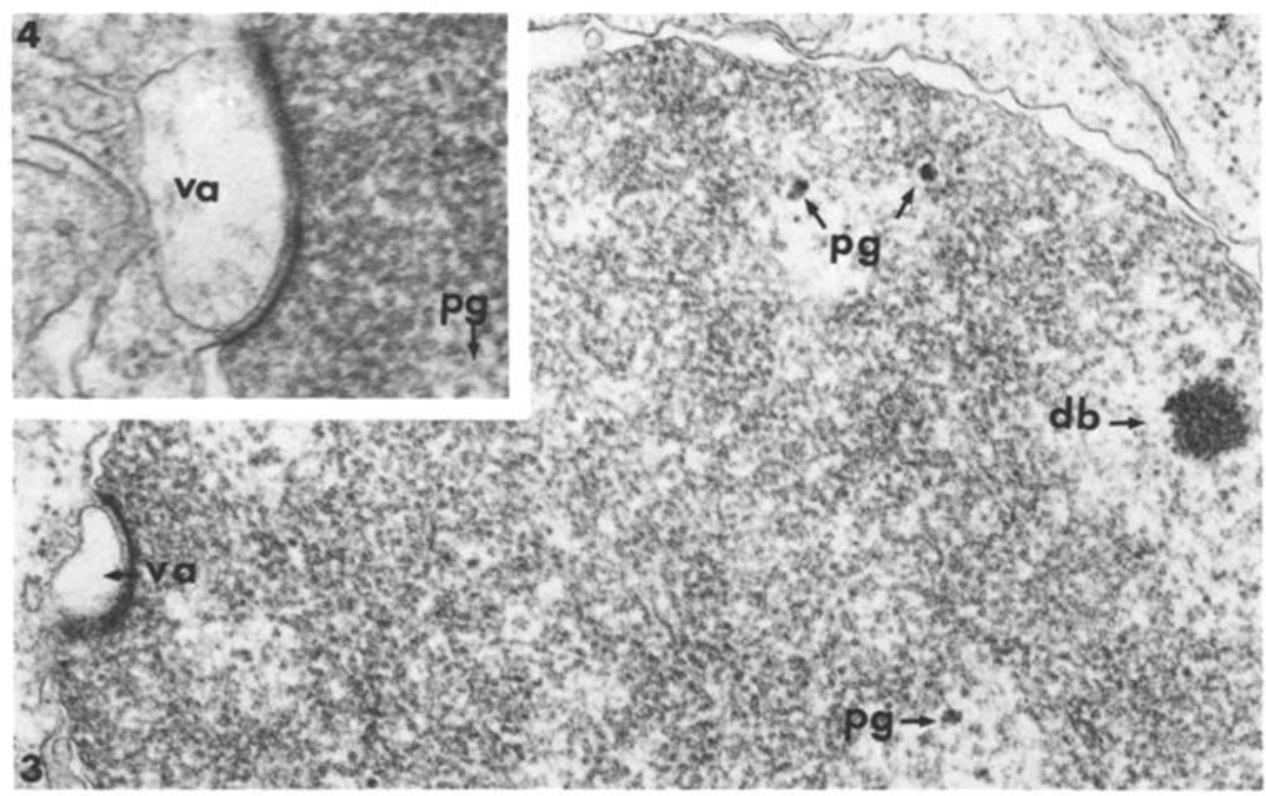

Fig. 3. Round spermatid (stage I) with vacuole ( $v a)$ attached to the nuclear envelope. Perichromatin granules $(\mathrm{pg})$ and a dense body $(d b)$ (nucleolus?) are visible in the nucleus. $\times 30000$

Fig. 4. Juxtanuclear vacuole $(v a)$ showing a later stage of development than in Fig. 3. $\times 47000$

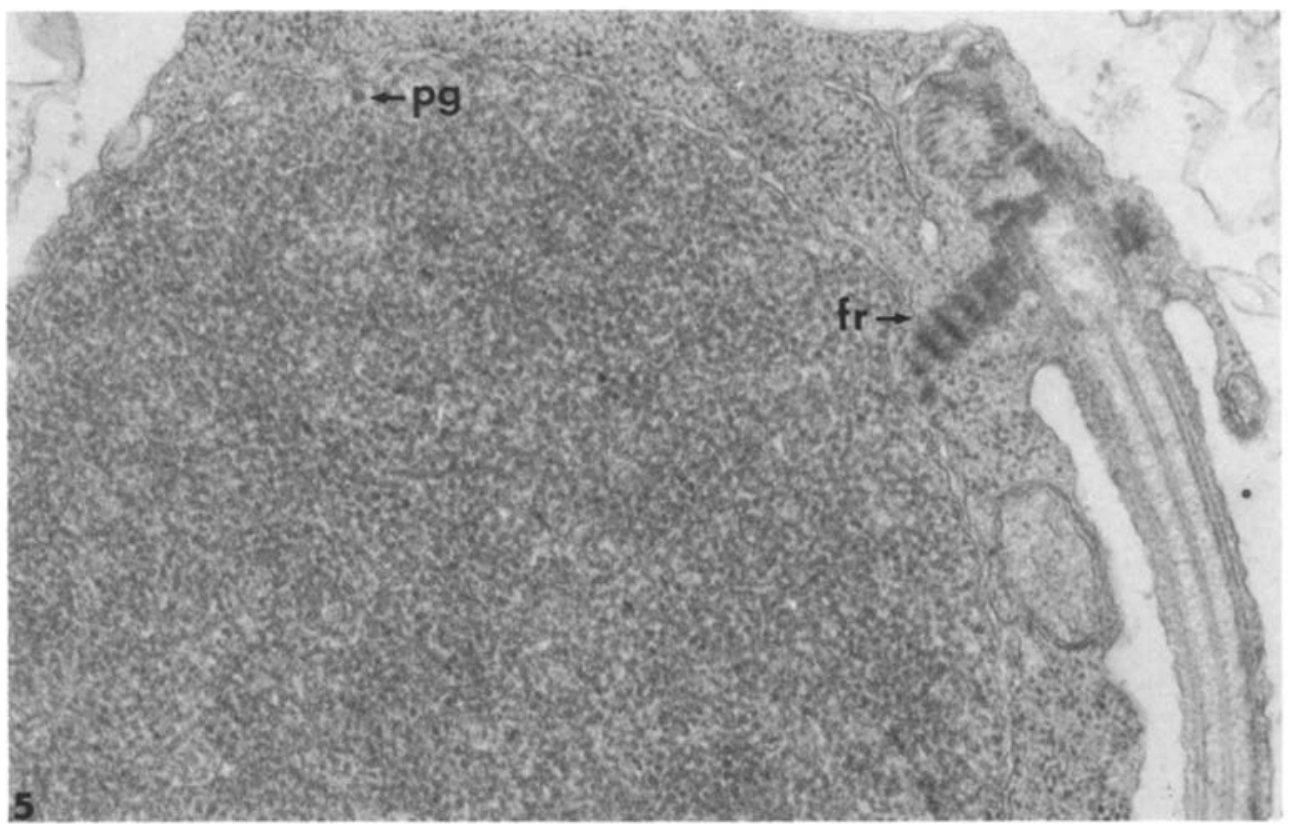

Fig. 5. Nucleus at stage II. The chromatin is becoming homogeneous. A flagellar rootlet (fr) links the nuclear envelope with the distal centriole. $\times 30000$ 


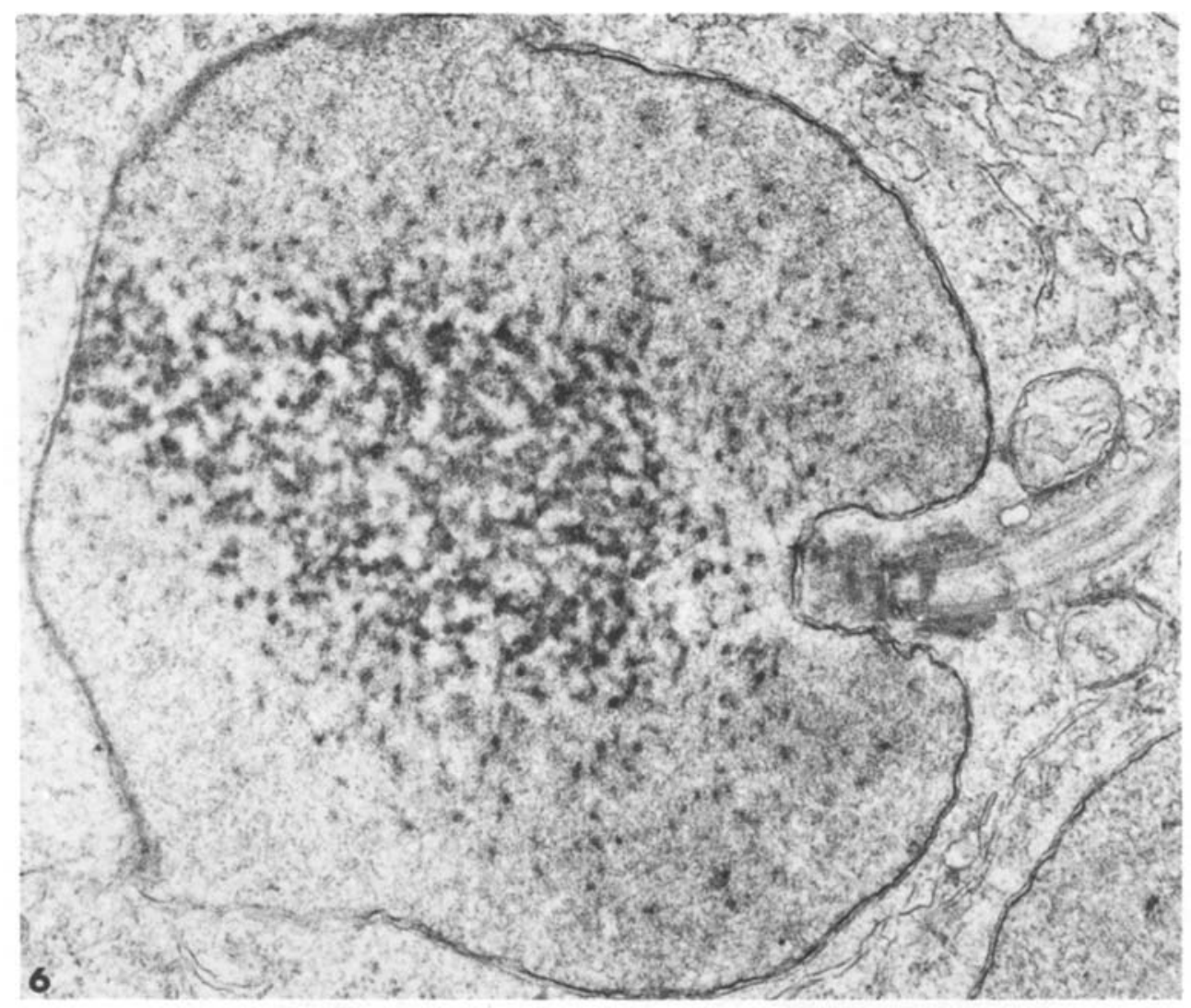

Fig. 6. Spermatid (stage III). Note the beginning of chromatin condensation in the form of coarse granules in the central part. Fixation in $\mathrm{OsO}_{4} . \times 32000$

implantation fossa (Figs. 6-9). Two types of material are identified in the nucleus: (i) very fine fibers at the periphery and coarse, fused granules, and (ii) much thicker fibers in the center (Fig. 6). Eventually, these thick fibers occupy the entire center of the nucleus and appear to show a definite orientation (Figs. 7-9). The thick fibers finally appear to condense, starting from the central axis of the nucleus and leaving some clear areas with a limited amount of material (Figs. 7-9). The cytoplasm is progressively pushed towards the posterior part of the spermatid (Figs. 7-9). In the anterior part of the spermatid, the modified nuclear envelope, identified during stage 1 , is clearly visible (Figs. 6-9). The final, rough morphology of the sperm head is then acquired with the mitochondria located in the posterior part of the spermatid (Figs. 7,9) and the centriolar complex inserted in the implantation fossa of the nucleus (Figs. 6-9). The flagellar rootlét associated with the distal centriole (Figs. 2,5) appears to be involved in the migration of this complex towards the nucleus (Figs. 8, 4, 10). The membranous structures are still poorly developed in the cytoplasm but the ribosomes are numerous. 


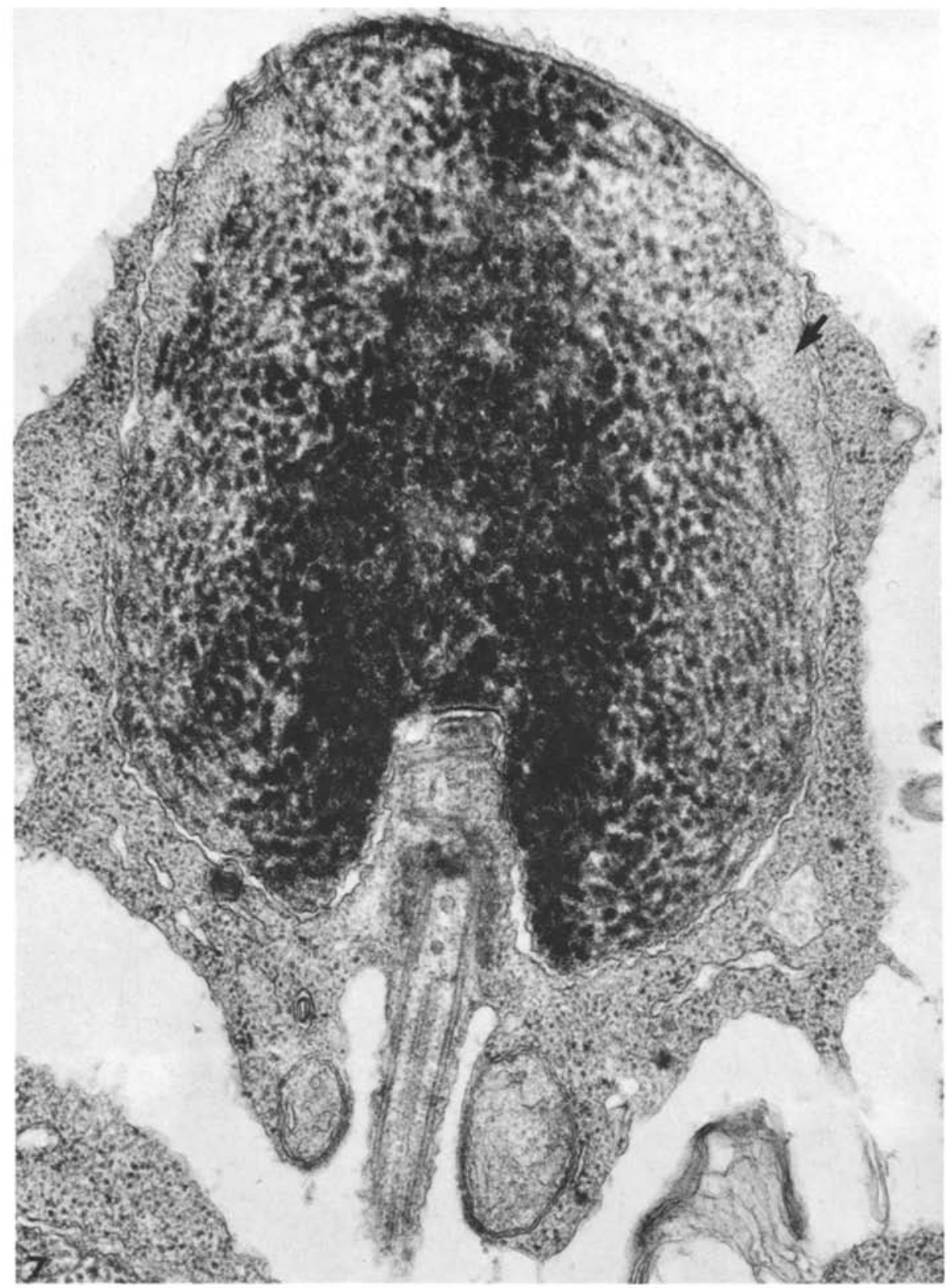

Fig. 7. Spermatid at stage III. Note the gradual extension of chromatin condensation to the periphery of the nucleus. Arrow indicates a zone of uncondensed chromatin. $\times 33000$ 


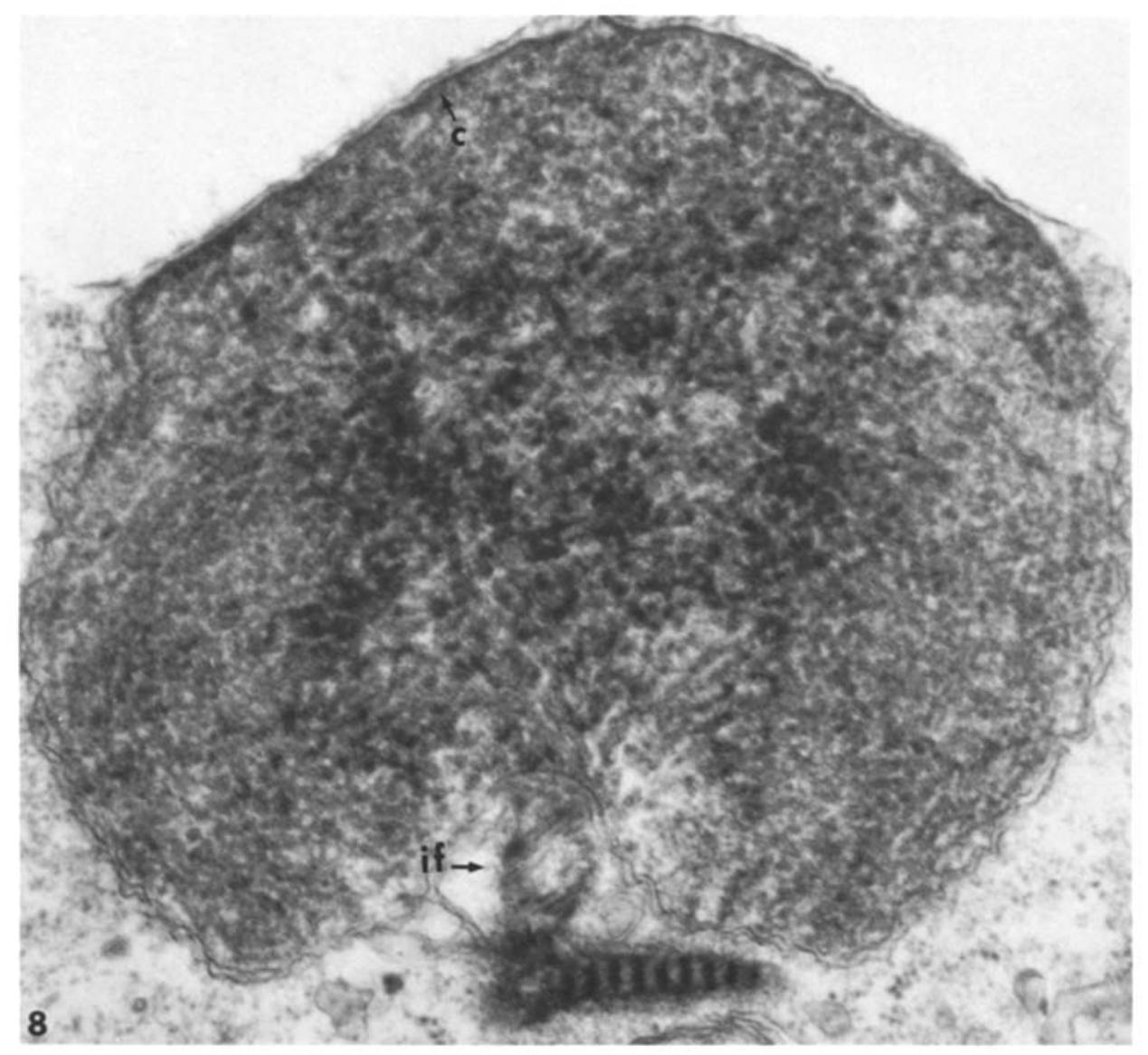

Fig. 8. The proximal centriole is located in the implantation fossa (if). First signs of chromatin condensation (stage III); $c$ chromatin condensation along the modified nuclear envelope. $\times 36000$

Stage 4. The nucleus maintains its elongated shape during this stage (Figs. 10, 12, 14). The chromatin becomes more condensed, starting with the formation of thick fibers (the ribbon-like element of Zirkin), composed of smooth fibrillar elements resulting from this condensation (Figs. 10, 12). The ribbon-like structure, but not the fibrillar elements, remain visible in late spermatids (Fig. 13) and in spermatozoa (Fig. 14). However later, at the end of the period of spermiation in February, the fibrillar elements are seen again in the degenerating sperm head in the lobule (Fig. 15). In spermatozoa in the testis or in ejaculated milt, the degree of chromatin condensation is quite variable, some sperm heads being entirely electrondense while others show numerous clear areas. The modified appearance of the nuclear envelope in the anterior part of the spermatid head, identified during the previous stages, is not visible in this stage but it is still present 


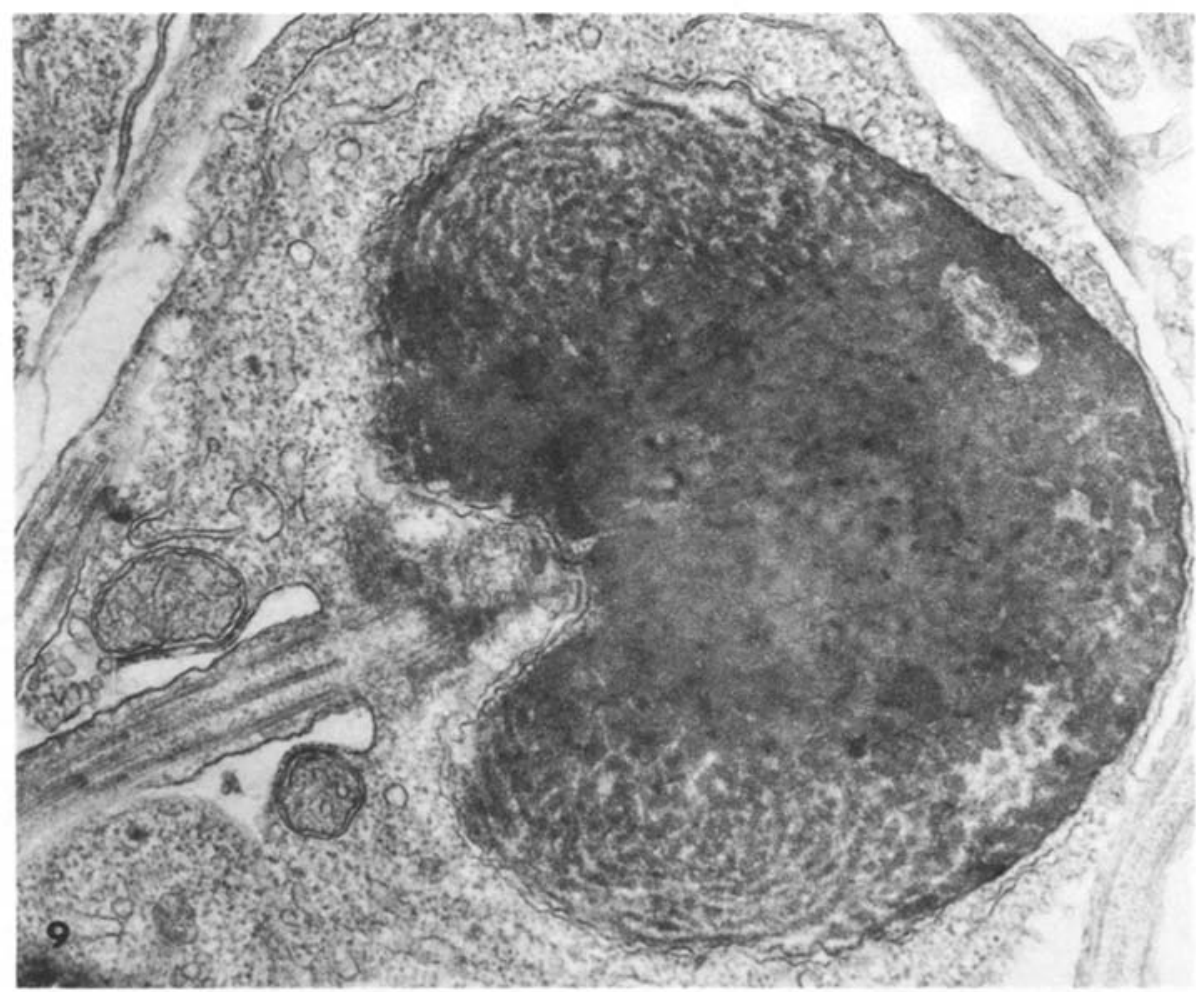

Fig. 9. Spermatid at stage III. The process of chromatin condensation has reached the periphery of the nucleus; the coarse granules and fibers fuse in the central part. $\times 30000$

because it can be seen again in degenerating spermatozoa found later in the lumen of the lobule (Fig. 15). During final development of the spermatid and the slight elongation of the nucleus, the flagellar rootlet (Fig. 11) remains associated with the distal centriole and in close contact with the nuclear envelope (Fig. 10). The rootlet disappears when the sperm head is fully formed (Fig. 14). The mitochondria are still found lining the cytoplasmic canal in the anterior part of the flagellum (Figs. 10, 12, 13); they tend to fuse and a single mitochondrion is usually found surrounding the cytoplasmic canal (Fig. 16). Some of the mitochondria not incorporated into the mid-piece are eliminated and occur isolated or associated with other organelles in residual bodies in the extracellular space (Fig. 17). The cytoplasm, which has been gradually pushed backwards during spermiogenesis, is finally detached from the spermatid (Fig. 14) and left in the cyst, from which cellular debris is taken and phagocytized by the Sertoli cells (Fig. 17); some debris remains in the lumen of the lobule. At no time during spermiogenesis does the head of the spermatid enter into close contact with the Sertoli cell cytoplasm. At the end of spermatogenesis, the cyst wall facing the central lumen of the lobule ruptures, and the spermatozoa are 


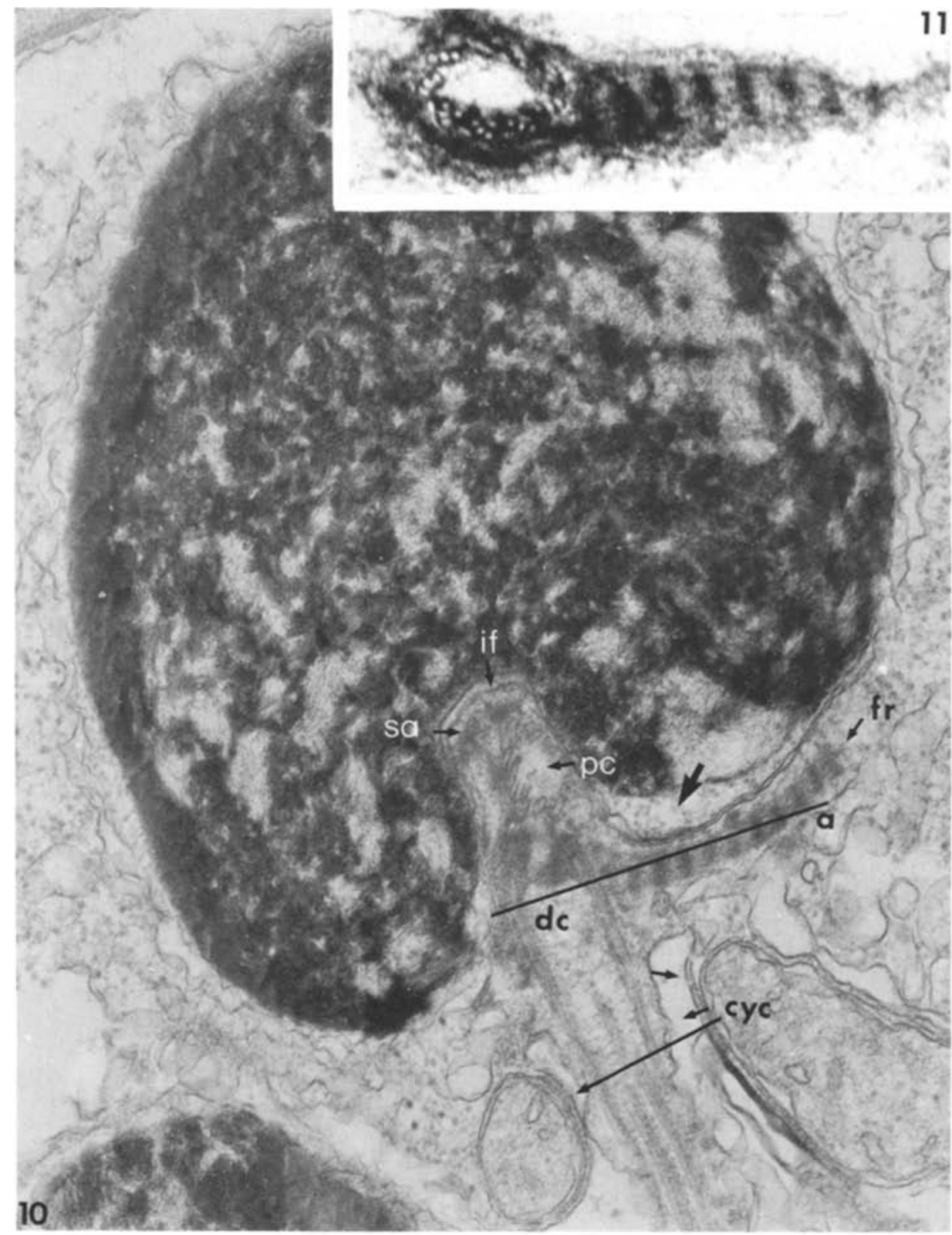

Fig. 10. Anterior-posterior section of a spermatid at stage IV. The flagellar rootlet $(f r)$ is still attached to the distal centriole $(d c)$ deeply embedded in the implantation fossa (if). The system of centriolar complex attachment to the nucleus is now formed. An additional membrane (arrow) can be seen between the plasma membrane of the cytoplasmic canal (cyc) and the mitochondrial envelope. Large arrow indicates a zone of uncondensed chromatin. $\times 45000$

Fig. 11. Detail showing the flagellar rootlet sectioned along the line shown in Fig. 10. $\times 60000$ 


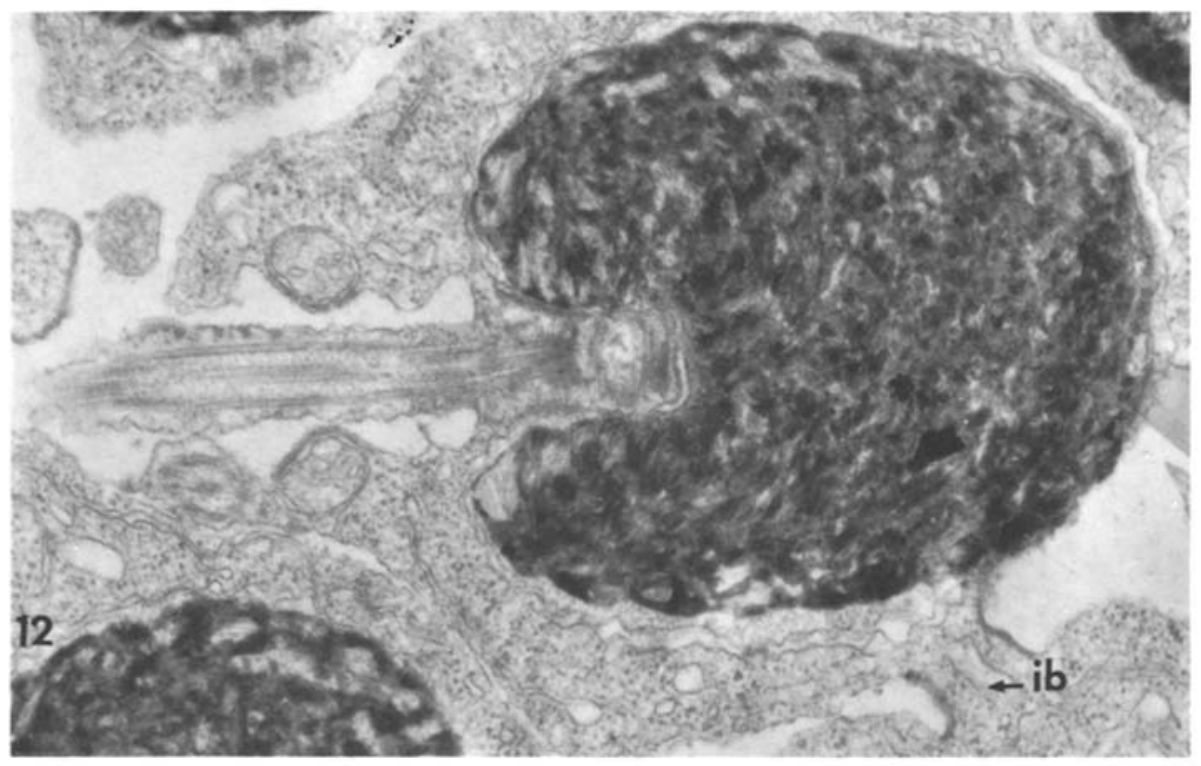

Fig. 12. Spermatid at stage IV. Ribbon-like elements appear in the nucleus. The spermatids remain attached by intercellular bridges $(i b)$. The cytoplasm is shifted to the posterior part of the spermatid. $\times 28000$

freed into the lumen. The Sertoli cells remain in a monolayer at the internal periphery of the lobule.

Spermatids at different stages are sometimes found side by side, showing that spermiogenesis is not always synchronous. Also, some cells do not appear to go through the entire process of spermiogenesis, remaining in the spermatid stage in the lumen of the lobule. Sometimes, the cyst opens prematurely, releasing the spermatids into the lumen of the lobule.

\section{Discussion}

Spermiogenesis in rainbow trout appears to be a relatively complex process. Zirkin (1975) divided this process into four stages based only on the degree of transformation of nuclear material. These stages also correspond to changes in other cellular components (Table 1).

With regard to changes in the nuclear material, the present findings are in agreement with the observations of Zirkin (1975) on Oncorhynchus tshawytscha; the main difference is that the so-called fibrils, identified at the beginning of stage 3 , seem to compose the ribbon-like elements of the trout. In this species, as well as in other salmonids, nucleohistones (very homogeneous in trout: Seyedin and Cole 1981) are transformed directly into nucleoprotamine due to the replacement of histones by protamine during spermiogenesis (Marushige and Dixon 1971; Louie and Dixon 1972; Dixon and Smith 1968). This transformation is said to occur at an advanced stage 


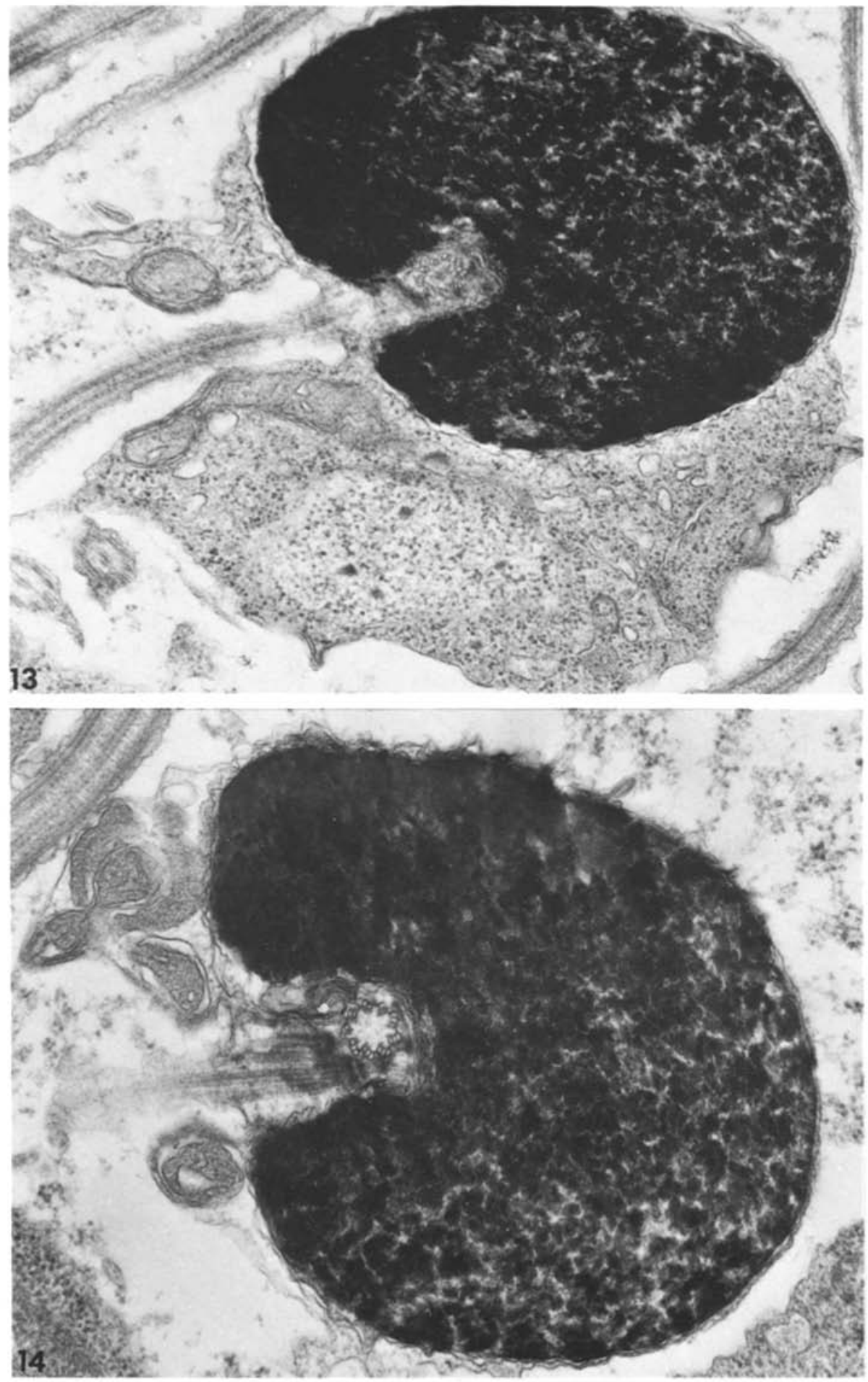

Fig. 13. Late stage-IV spermatid. $\times 30000$

Fig. 14. A spermatozoon is shorter after the cytoplasm has finally been eliminated. $\times 35000$ 


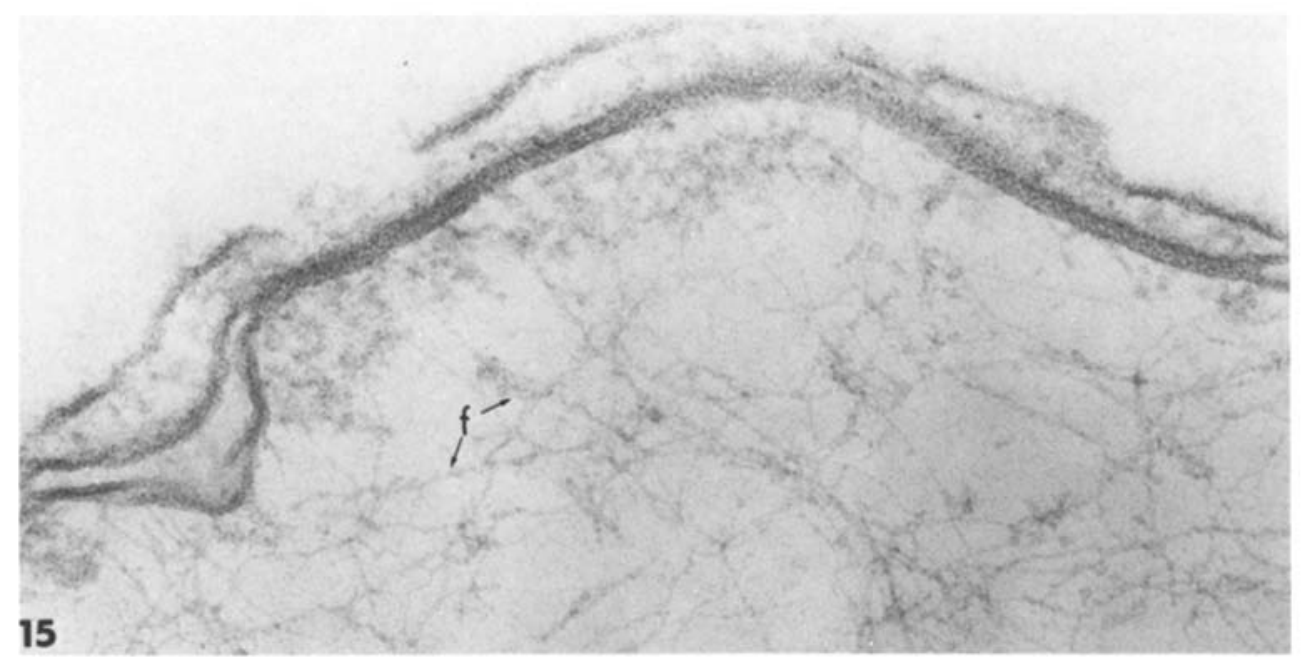

Fig. 15. Detail showing differentiation of the nuclear envelope in a degenerating sperm head in the lobular lumen. Dense material is condensed between the two layers of the envelope; $f$ chromatin fibrils. $\times 96000$

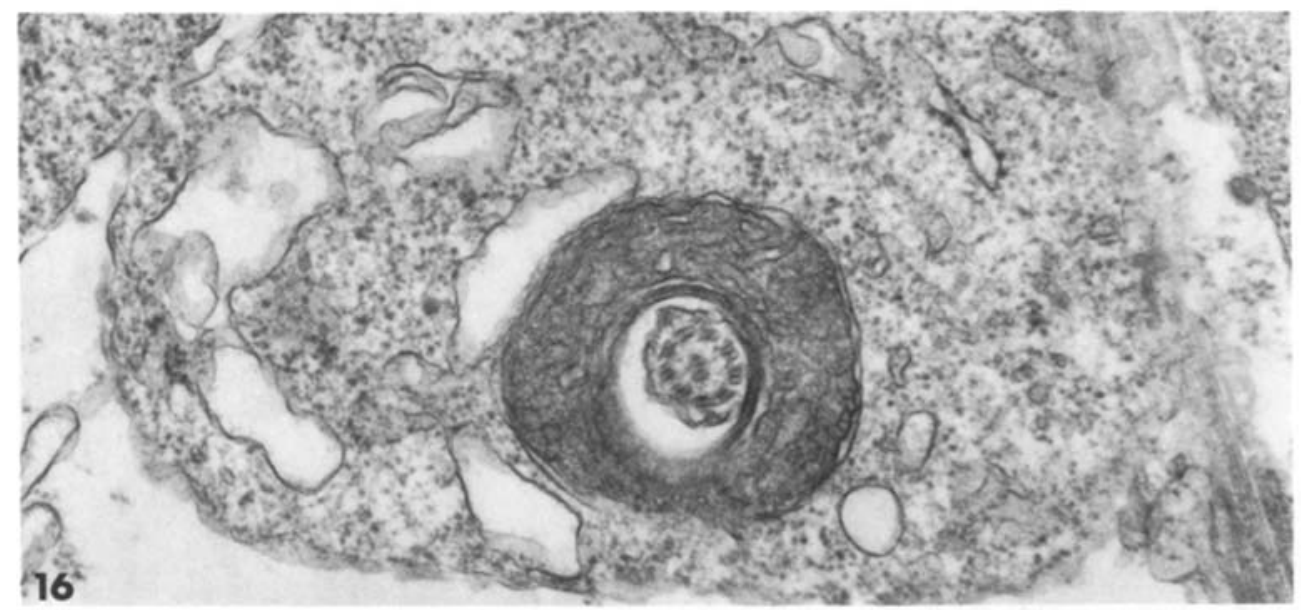

Fig. 16. Cross-section of the posterior part of a late spermatid showing annular mitochondria. $\times 30000$

of spermiogenesis (Alfert 1956) or in the middle phase of spermatid development (Louie and Dixon 1972). In addition, protamine undergoes enzymatic phosphorylation and dephosphorylation (Louie and Dixon 1974). It is supposed that the two phenomena, i.e. the appearance of protamine and phosphorylation-dephosphorylation, are connected with chromatin condensation, but the exact stages of this process are not known. More investigations are necessary to determine if there is a relationship between the two major 


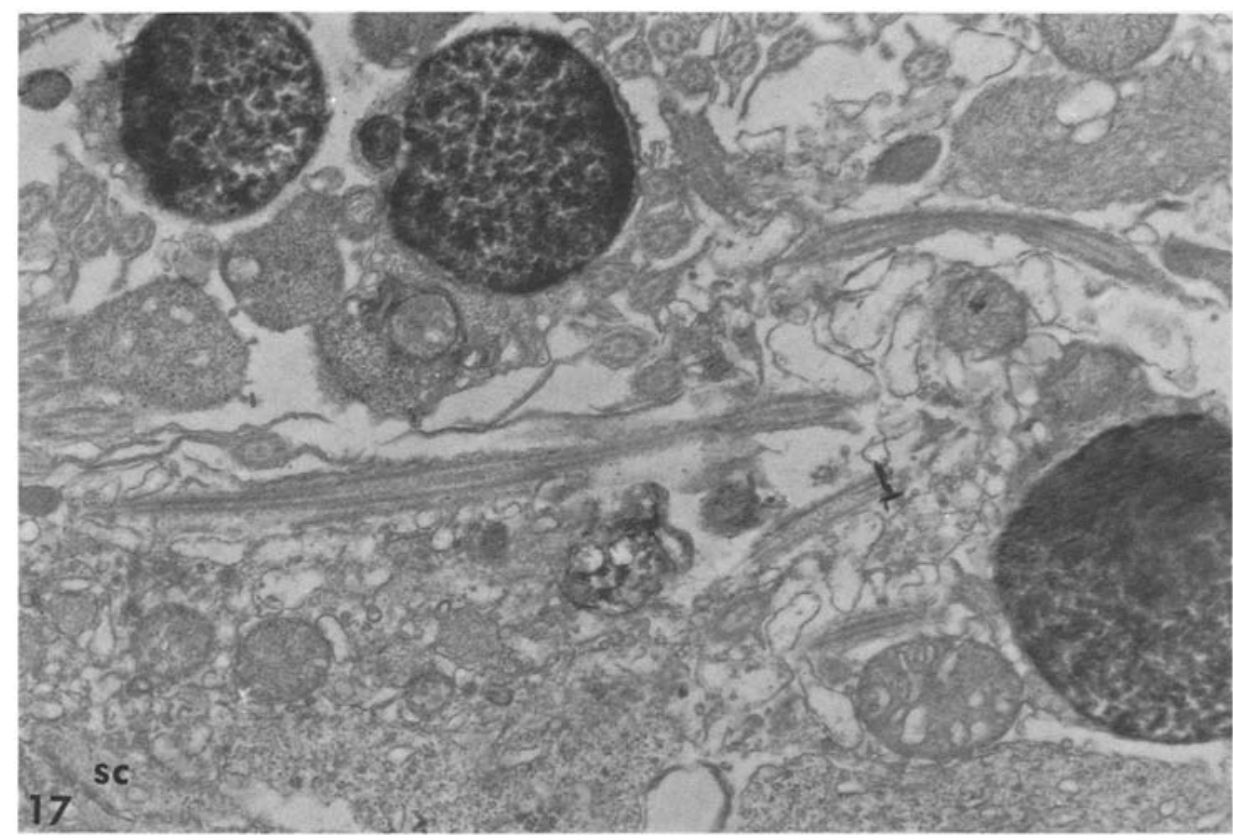

Fig. 17. Lumen of a lobule with free spermatozoa and various residual bodies; $S c$ Sertoli cell. $\times 15000$

events of chromatin alteration in spermatids, i.e. the formation of thick fibers and the appearance of the smooth fibrils associated with the ribbonlike elements.

The presence of nucleoprotamine fibrils has also been reported in mature trout sperm after extraction in ammonium acetate (Inoue and Fuke 1970) and treatment with $\mathrm{NaCl}$ (Pollister and Mirsky 1946; Felix 1960). Fibrils can be observed in degenerating sperm nuclei in the testis (Fig. 18) or in the sperm duct (Billard and Takashima 1983) and after deep freezing (Billard 1983), indicating that this fibrillar association is not very tight and can be disrupted easily. The sperm head has been found to change in size with differences in the osmotic pressure of the fixative (Lowman 1953), but not with differences in the osmotic pressure of the saline solution (Billard and Breton 1970). Some morphological changes also occur after dilution in fresh water (Billard 1978).

The cytoplasm has relatively few organelles. The dense material (intermitochondrial 'cement'), very abundant in cyprinids (Clerot 1976), is quite scarce in trout. Possibly as a result of this (Toury et al. (1977) have suggested that the cement is incoporated into the mitochondria), the number of mitochondria is limited and the mid-piece is relatively small, consisting of a single mitochondrion shaped like an incompletely closed ring. The final structure of the mid-piece is gradually acquired while the spermatozoa rest in the lumen of the lobule. A kind of structural maturation then occurs after the spermatozoa are released from the cyst. This may be related to 


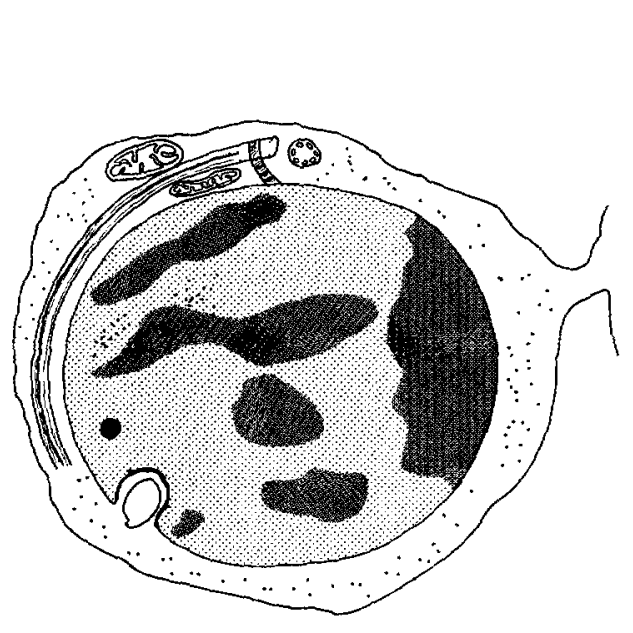

(1)

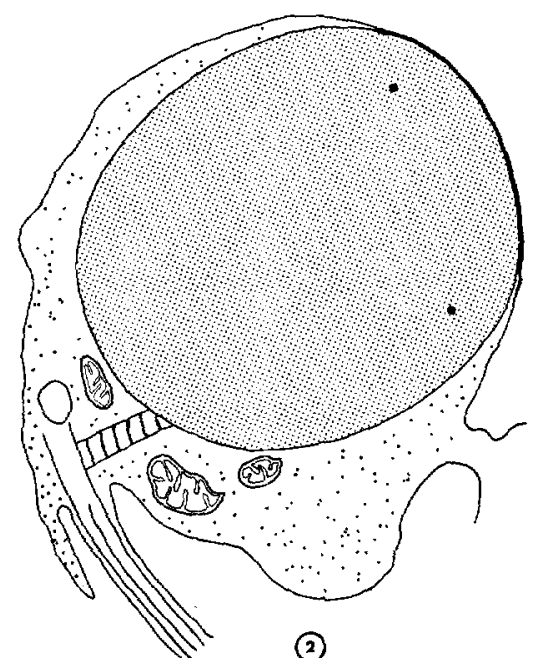

(2)

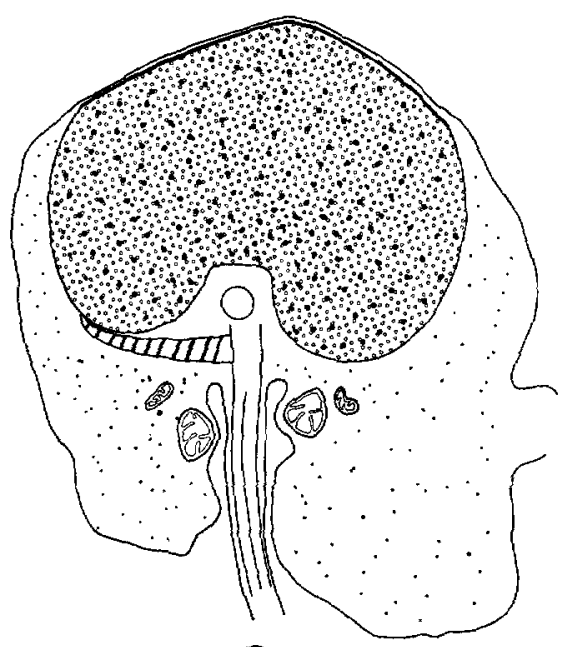

(3)

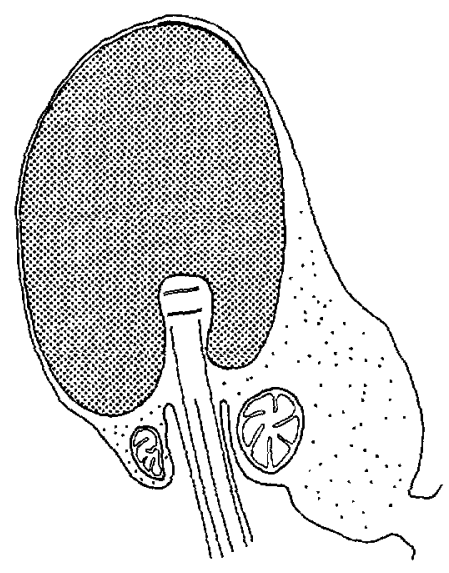

(4)

Fig. 18. Summary of the major changes occurring during spermiogenesis in trout

a change in sperm physiology; for instance, the motility of intratesticular spermatozoa is not inhibited by $\mathrm{K}^{+}$at the very end of spermatogenesis as it is once spermiation has started (Billard and Mattéi, unpublished).

It is now well established that teleost fish have no acrosome. However, a vacuole very similar to the acrosome vacuole, visible at the beginning of acrosome formation in mammals, is identified in trout; this may represent an attempt to form the acrosome. Differentiation and densification of the nuclear envelope are observed in the anterior part of spermatids and sperma- 
tozoa in trout (Fig. 15; Billard 1983) and in Lepadogaster lepadogaster (Mattéi and Mattéi 1978). These authors interpreted this structure as a vestigial acrosome. This differentiated nuclear envelope might play a role in the process of membrane fusion during fertilization. The anterior part of the sperm head first seems to be in contact with the eggs at the bottom of the micropyle in trout (Ginsburg 1963) as well as in Oryzias latipes (Iwamatsu and Ohta 1981) and carp (Kuo 1980). Differentiation of the nuclear envelope also seems to prevent the anterior part of the envelope from swelling when the sperm is exposed to fresh water (Billard, unpublished observation).

Contrary to centrioles in the guppy, which cannot be recognized in mature spermatozoa (Billard 1969, 1970), the centriolar complex in trout undergoes only slight changes during spermiogenesis. At the beginning of this process, the axoneme without a plasma membrane is found in the cytoplasm (Fig. 1). The fusion of vesicles near the centriolar complex (Fig. 1), as in guppy (Billard and Flechon 1969) and Oryzias latipes (Sakai 1976), seems to be responsible for the formation of the membrane and the anterior part of the cytoplasmic canal. The remainder of the membrane appears to be formed when the flagellum is pushed outside the cell. The formation of the flagellum is different in trout compared to Trichiurus and some other teleosts in which the distal centriole remains attached to the plasma membrane (Mattéi and Mattéi 1976; Mattéi 1969).

Another interesting feature of trout spermiogenesis is the presence of a flagellar rootlet connected with the centriolar complex during the major morphological changes (elongation of the nucleus and attachment of the flagellum to the sperm head) in the spermatid. This rootlet, which may be constituted of contractile material, is possibly involved in the attraction and stabilization of the centriolar complex in the implantation fossa while the definitive structure attaching the centriolar complex to the nucleus (bars and filaments), and found in mature trout spermatozoa (Billard 1969, 1983), is progressively established. Data in the literature show that more or less complex associated cytoplasmic structures are present at the time the flagellum is attached to the nucleus; these include rootlets in trout, various structures such as intercentriolar lamellar bodies, electron-dense material and microtubules in Oryzias latipes (Grier 1976), Trichiurus lepturus (Mattéi and Mattéi 1976) or Pantolon bucholzi (Deurs and Lastein 1973), and bundles of microtubules in poecilids (Billard 1970; Russo and Pisano 1973; Grier 1975). In some cases, microtubules are associated with rootlets (eel, Albula: Billard and Ginsburg 1973; Mattéi and Mattéi 1974) or with satellites and fibrous material as in Upeneus prayensis (Boisson et al. 1969). Such direct means of anchoring the centriolar complex to the nucleus may be completed by additional cytoplasmic structures increasing the strength and rigidity of the system; these structures include thickening of the plasma membrane limiting the cytoplasmic canal in Trichiurus lepturus (Mattéi and Mattéi 1976) or the well-developed mid-piece in poecilids and other species with an elongated nucleus (except for Anguilla anguilla which has no midpiece but perinuclear microtubules that remain in the mature spermatozoa). 
Rootlets are not observed in species like pike or carp in which the sperm head remains spherical and the flagellar attachment is very simple, i.e. only in contact with the nuclear envelope (Billard 1969; Caloianu-Iordächel and Sicoe 1976). As complex structures for attaching the flagellum to the nucleus are present only in spermatids that undergo complex spermiogenesis, and as these structures coincide with the elongation of the nucleus and chromatin condensation, they are also involved in these events; this is the case for microtubules. A role in shaping the nucleus has been given to the manchette, but Fawcett et al. (1971) demonstrated that such a role was not obvious and suggested that the shape of the nucleus might be determined by forces resulting from the aggregation of DNA and protein during chromatin condensation. However, Courtens and Loir (1981) proposed that microtubules might play a role in the organization of chromatin and its transformation. This hypothesis would not apply in the case of trout since chromatin condensation occurs without the presence of a manchette or microtubules. Courtens (1982) suggested that the flagellum itself might play a similar role; in the case of salmon, the insertion of the flagellum into the implantation fossa may be responsible for the radial orientation of the chromatin fibers observed by Zirkin (1975).

The mechanism controlling the transformation of nuclear material during spermiogenesis is not clear. The suggestions of Jergil and Dixon (1970) and Marushige and Dixon (1971) regarding endocrine control have not been confirmed, although it has been shown that plasma gonadotropin and androgens rise markedly during spermiogenesis (Billard et al. 1978; Scott et al. 1980; Stuart-Kregor et al. 1981; Hunt et al. 1982) and that steroidogenic activity is detectable in Sertoli cells of spermatid cysts (Hurk et al. $1978 \mathrm{a}, \mathrm{b})$. More generally, the fact that most spermatids are not in direct contact with the Sertoli cells is intriguing in a species in which morphological and biochemical changes in the spermatid head are important. In the guppy, all the spermatids are in direct contact with the Sertoli cells at the end of spermatogenesis but the transformations in guppy are more extensive than in trout. However, in trout the spermatids have indirect contact with the Sertoli cells via the intercellular bridges that seem to connect all the cells in a cyst, as shown in other fish (Clerot 1971; Grier 1976) and mammals (Dym and Fawcett 1971). Secretory material found inside the cyst and originating from the Sertoli cells represents another indirect way of contact between the spermatids and the Sertoli cells. In turn, in salmonids some signals reaching the Sertoli cells may be emitted by the spermatids. Spermatogenesis is discontinuous, generally ceasing in autumn, although the endocrine environment (gonadotropin and steroids) still seems favorable. Further spermatogonial division may be inhibited when the testis reaches a given size (sperm release starts only one month after the end of spermatogenesis so that the testis continues to increase in size until spermatogenesis ceases). Compensatory hypertrophy has also been shown in trout (Billard et al. 1982). Therefore, a chalone-type substance may be involved and signals emitted from the spermatids via the release of nuclear or cytoplasmic material. This nuclear material, eliminated during spermiogenesis or taken from 
the cyst to be phagocytized (Billard et al. 1972), has informative value and could play a role in the control of spermatogenesis.

Acknowledgements. The skilled assistance of Mrs. D. Huneau is acknowledged. The photographs were prepared by R. Scandolo and the English manuscript by Mrs. A. Daifuku. We thank Dr. M. Loir for his criticism and comments.

\section{References}

Alfert M (1956) Chemical differentiation of nuclear proteins during spermatogenesis in the salmon. J Biophys Biochem Cytol 2:109-114

Billard R (1969) Ultrastructure comparée des spermatozoïdes de quelques poissons téléostéens. Baccetti Ed Quaderno 137:71-79

Billard R (1970) La spermatogénèse de Poecilia reticulata. IV - La spermiogénèse; étude ultrastructurale. Ann Biol Anim Bioch Biophys 10:493-510

Billard R (1972) Racines flagellaires transitoires au cours de la spermiogénèse de la Truite Arc-en-ciel (Abstr). J Microsc 14:21 a

Billard R (1978) Changes in structure and fertilizing ability of marine and freshwater fish spermatozoa diluted in media of various salinities. Aquaculture 14:187-198

Billard R (1983) Ultrastructure of trout spermatozoa: Changes after dilution and deep-freezing. Cell Tissue Res 228:205-218

Billard R, Breton B (1970) Modifications ultrastructurales et cytochimiques des spermatozoïdes après dilution, chez les poissons d'eau douce. $7^{e}$ Congr Int Micro Electr, Grenoble 637-638

Billard R, Flechon JE (1969) Spermatogonies et spermatocytes flagellés chez Poecilia reticulata (Téléostéen cyprinodontiforme). Ann Biol Anim Bioch Biophys 9:281-286

Billard R, Ginsburg AS (1973) La spermiogénèse et le spermatozoïde d'Anguilla anguilla L. Ann Biol Anim Bioch Biophys 13:523-534

Billard R, Takashima F (1983) Resorption of spermatozoa in the sperm duct of rainbow trout (Salmo gairdneri) during the post-spawning period. Jap Bull Soc Sci Fish, 49:387-392

Billard R, Jalabert B, Breton B (1972) Les cellules de Sertoli des poissons téléostéens. Ann Biol Anim Bioch Biophys 12:19-32

Billard R, Breton B, Fostier A, Jalabert B, Weil C (1978) Endocrine control of the teleost reproductive cycle and its relation to external factors: salmonid and cyprinid models. In: Gaillard PJ, Boer HH (eds) Comparative endocrinology. Elsevier North-Holland Biomedical press, Amsterdam, pp 37-48

Billard R, Crim LW, Peter RE, Breton B (1982) Long-term changes in plasma and pituitary GTH after castration of rainbow trout at an immature stage. In: Richter CJJ, Goos HJTh (Comp.) Reproductive physiology of fish, PUDOC Amsterdam, pp 50

Boisson C, Mattéi X, Mattéi C (1969) Mise en place et évolution du complexe centriolaire au cours de la spermiogénèse d'Upeneus prayensis C.V. (poisson mullidae). J Microsc $8: 103-112$

Caloianu-Iordächel M, Sicoe Z (1976) Ultrastructura gametilor masculi la douä specii de teleosteeni (Stizostedion lucioperca L. si Cyprinus carpio L.) St Si Cerc Biol Seria Biol Anim 28:95-100

Clerot JC (1971) Les ponts intercellulaires du testicule du gardon: organisation cyncitiale et synchronie de la différenciation des cellules germinales. J Ultrastruct Res 37:690-703

Clerot JC (1976) Les groupements mitochondriaux des cellules germinales des poissons Téléostéens Cyprinidés. I. Étude ultrastructurale. J Ultrastruct Res 54:461-475

Courtens JL (1982) Rôles indirects des microtubules dans la morphogénèse nucléaire des spermatides. Reprod Nutr Dev 22:825-840

Courtens JL, Loir M (1981) The spermatid manchette of mammals: formation and relation with the nuclear envelope and the chromatin. Reprod Nutr Dev $21: 467-477$

Davies PL, Dixon GH, Ferrier LN, Gedamu L, Iatrou K (1976) The structure and function of protamine mRNa from developing trout testis. Prog Nucl Acid Res Mol Biol 19:135-155. Academic Press, New York London 
Deurs B van, Lastein U (1973) Ultrastructure of the spermatozoa of the teleost Pandodon buchholzi Peters, with particular reference to the midpiece. J Ultrastruct Res 42:517-533

Dixon H, Smith M (1968) Nucleic acids and protamine in salmon testes. Prog Nucl Acid Res Mol Biol 8:9-33, Academic Press, London New York

Dym M, Fawcett DW (1971) Further observations on the numbers of spermatogonia spermatocytes, and spermatids connected by intercellular bridges in the mammalian testis. Biol Reprod 4:195-215

Fawcett DW, Anderson WA, Phillips DM (1971) Morphogenetic factors influencing the shape of the sperm head. Dev Biol 26:220-251

Felix K (1960) Protamines. Ad Protein Chem 15:1-56

Ginsburg AS (1963) Sperm egg association and its relationship to the activation of the egg in salmonid fishes. J Embryol Exp Morphol 11:13-33

Grier HJ (1975) Spermiogenesis in the teleost Gambusia affinis with particular reference to the role played by microtubules. Cell Tissue Res 165:89-102

Grier HJ (1976) Sperm development in the teleost Oryzias latipes. Cell Tissue Res 168:419:431

Hunt SMV, Simpson TH, Wright RS (1982) Seasonal changes in the levels of 11-oxotestosterone and testosterone in the serum of male salmon, Salmo salar L., and their relationship to growth and maturation cycle. J Fish Biol 20:105-119

Hurk R van den, Vermeij JAJ, Stegenga J, Peute J, Oordt PGWJ van (1978a) Cyclic changes in the testis and vas deferens of the rainbow trout (Salmo gairdneri) with special reference to sites of steroidogenesis. Ann Biol Anim Bioch Biophys 18:899-904

Hurk R van den, Peute J, Vermeij JAJ (1978b) Morphological and enzyme cytochemical aspects of the testis and vas deferens of the rainbow trout, Salmo gairdneri. Cell Tissue Res 186:309-325

Inoue S, Fuke M (1970) An electron microscope study of deoxyribonucleoprotamines. Biochim Biophys Acta 204:296-303

Iwamatsu T, Ohta T (1981) Scanning electron microscopic observations on sperm penetration in teleostean fish. J Exp Zool 218:261-277

Jergil B, Dixon GH (1970) Protamine kinase from rainbow trout testis. J Biol Chem $245: 425-434$

Kuo S (1980) Sperm penetration and the formation of a fertilization cone in the common carp egg. Dev Growth Differ 22:403-414

Louie J, Dixon GH (1972) Trout testis cells. I - Characterization by deoxyribonucleic acid and protein analysis of cells separated by velocity sedimentation. $J$ Biol Chem 247:5490-5497

Louie J, Dixon GH (1974) Enzymatic modifications of the protamines. II - Separation and characterization of phosphorylated species of protamines from trout testis. Can $\mathrm{J}$ Biochem $52: 536-546$

Lowman FG (1953) Electron microscope studies of silver salmon spermatozoa (Oncorhynchus kisutch Walbaum). Exp Cell Res 5:335-360

Marushige K, Dixon GH (1971) Transformation of trout testis chromatin. J Biol Chem 246:5799-5805

Mattéi X (1969) Spermiogénèse comparée des poissons. Baccetti Ed Quaderno 137:57-69

Mattéi C, Mattéi X (1974) Spermiogenesis and spermatozoa of the Elopomorpha (teleost fish). In: Afzelius (ed) The functional anatomy of the Spermatozoon. Pergamon Press, Oxford New York, pp 211-221

Mattéi X, Mattéi C (1976) Ultrastructure du canal cytoplasmique des spermatozoïdes de Téléostéens illustrée par l'étude de la spermiogénèse de Trichiurus lepturus. J Microse Biol Cell $25: 249-258$

Mattéi C, Mattéi X (1978) La spermiogénèse d'un poisson Téléostéen (Lepadogaster lepadogaster). I. La spermatide. Biol Cellulaire 32:257-268

Pollister AW, Mirsky AE (1946) The nucleoprotamine of trout sperm. J Gen Physiol $30: 101-117$

Russo J, Pisano A (1973) Some ultrastructural characteristics of Platypoecilus maculatus spermatogenesis. Boll Zool 40:201-207

Sakai YT (1976) Spermiogenesis of the teleost, Oryzias latipes, with special reference to the formation of flagellar membrane. Dev Growth Differ 18:1-13 
Scott AP, Bye VJ, Baynes SM, Springate JRC (1980) Seasonal variations in plasma concentrations of 11-ketotestosterone and testosterone in male rainbow trout, Salmo gairdnerii Richardson. J Fish Biol 17:495-505

Seyedin SM, Cole RD (1981) H1 histones of trout. J Biol Chem 256:442-444

Stuart-Kregor PAC, Sumpter JP, Dodd JM (1981) The involvement of gonadotrophin and sex steroids in the control of reproduction in the parr and adults of Atlantic salmon, Salmo salar L. J Fish Biol 18:59-72

Toury R, Clérot JC, André J (1977) Les groupements mitochondriaux des cellules germinales des poissons Téléostens Cyprinidés. IV. Analyse biochimique des constituants du "ciment" intermitochondrial isolé. Biol Cellulaire 30:225-232

Zirkin BR (1975) The ultrastructure of nuclear differentiation during spermiogenesis in the salmon. J Ultrastruct Res 50:174-184

Accepted April 25, 1983 